\title{
Physiological Investigations on Response of Post Emergence Application of Weedicides in Maize [Zea mays $\left(L_{0}\right)$ ]
}

\author{
Satyendra Thakur*, A. S. Gontia and Rohit Kumar Kumawat \\ Department of Plant Physiology, Jawaharlal Nehru Krishi Vishwa Vidyalaya, Jabalpur, \\ (Madhya Pradesh) India \\ *Corresponding author
}

\section{A B S T R A C T}

\section{Keywords}

Maize, Post

emergence

weedicides,

Mesotrione,

Paraquat dichloride,

Tembotrione,

Physiological traits,

Yield performance,

Proximate analysis

Article Info

Accepted:

07 November 2020

Available Online:

10 December 2020
A field experiment entitled "Physiological investigations on response of post emergence application of weedicides in maize [Zea mays (L.)]" was conducted at Research Farm, AICRP on Forage Crops, Department of Agronomy, JNKVV, Jabalpur (Madhya Pradesh) during Kharif season of the year 2018-19. The treatments comprised of 7 weeds control methods viz. application of mesotrione 40\%SC@250mlha ${ }^{-1}$, mesotrione 40\%SC @ 300 $\mathrm{mlha}^{-1}$, mesotrione 40\% SC @ 350mlha ${ }^{-1}$, paraquat dichloride 24\% SL @ 2000ml ha ${ }^{-1}$, tembotrione $34.3 \%$ SC @ 286 $\mathrm{ml} \mathrm{ha}^{-1}$, one plot was kept weeds free and another kept untreated in each replication. The research experiment was laid out in a randomized block design replicated thrice. Treatment $\mathrm{T}_{6}$ (Hand weeding) possessed an average higher value for dry matter production at initial $(1.861 \mathrm{~g})$ and at maturity $(347.16 \mathrm{~g})$, an average higher LAI (3.25), LAD (66292.62 $\mathrm{cm}^{2}$.days) and CGR $\left(0.008879 \mathrm{gcm}^{-2} \mathrm{day}^{-1}\right)$. Higher magnitudes of physiological traits in $\mathrm{T}_{6}$ (Hand weeding) had reflected to its highest grain yield (2812.423 $\mathrm{kgha}^{-1}$ ). Treatment $\mathrm{T}_{5}$ (tembotrione $34.3 \%$ SC @ 286mlha ${ }^{-1}$ ) was adjudged second in yield performance $\left(2623.45 \mathrm{kgha}^{-1}\right)$. The treatment $\mathrm{T}_{7}$ (control) recorded the minimum seed yield $\left(1036.53 \mathrm{kgha}^{-1}\right)$. In proximate analysis treatment $\mathrm{T}_{6}$ (Hand weeding) registered maximum protein $(9.87 \%)$ and fat $(4.00 \%)$ contents. $\mathrm{T}_{3}$ (Mesotrione 40\%SC@350mlha ${ }^{-1}$ ) noted maximum amount of carbohydrate $(70.46 \%)$ and fiber $(2.73 \%)$, whereas $\mathrm{T}_{6}$ (Hand weeding) had highest value of ash content $(2.67 \%)$.

\section{Introduction}

Maize (Zea mays L.) is a $\mathrm{C}_{4}$ plant with a high photosynthetic potential, capable of producing high yields due to its high adaptive abilities hence it is also called as queen of cereals. It is the most popular cereal crop in the world alongside wheat and rice (Suleiman et al., 2015) and most important cereal grains grown worldwide in a wider range of environments because of its greater adaptability (Kogbe and Adediran, 2003). Because it was nutritious, easy to store and carry, adapted to diverse growing conditions and provided food and fuel, maize became a staple food for most American and Caribbean cultures. After Europeans arrived in America they took it home with them and it spread around the 
world, at present maize is cultivated around 150 million ha. area in world with 1,134 million tones production. As per first advance estimate published by ministry of agriculture and farm welfare on 26 September 2018, In India it is cultivated in an area of 8.7 million ha. with 21.47 million tones production and $2509.02 \mathrm{~kg} \mathrm{ha}^{-1}$ productivity (MoA and FW, GOI). In Madhya Pradesh the total area of maize is 1524.0 ha. with the production of 2350 t.ha $^{-1} \quad$ (Ministry of Agriculture, Anonymous. 2016). Generally maize is a single-stalk, monoecius plant belongs to family poaceae and have total number of chromosome $(2 n=20)$. It is mainly used as a food source and now has become the most important raw material for animal feed (Pimentel and Patzek, 2005). In India, over 85 percent of the maize production is used as food. Most commonly used forms are as Chapattis, boiled or roasted green ears, breakfast foods like corn flakes and Pop corn. Its grain has great nutritional value and contains about $9.9 \%$ protein, $4 \%$ oil, $70 \%$ starch and $2.7 \%$ crude fiber. Losses in corn green ear yield and grain yield in relation to growth as a consequence of weeds are due to several causes. Yield attributes, viz. cobs per plant, grains per cob and 100 grains weight were significantly lower due to presence of dominant weeds (Balyan and Bhan, 1987) in maize. For reducing yield losses due to impact of weeds several types of weedicides can be used.

Mesotrione is a triketone herbicide, with the empirical formula $\mathrm{C}_{14} \mathrm{H}_{13} \mathrm{NO}_{7} \mathrm{~S}$ and molecular weight equal to $339.32 \mathrm{~g} \mathrm{~mol}^{-1}$, characterized by moderate solubility in water $160 \mathrm{mg} \mathrm{L}^{-1}$ (at $20{ }^{\circ} \mathrm{C}$ ) (PPDB, 2014). Mesotrione is a selective and systemic herbicide applied post emergence that may indicated to control weeds infesting corn crop, (Rodrigues and Almeida, 2005). Its mode of action is to inhibit the enzyme 4-hydroxy phenol pyruvate dioxygenase (HPPD). This leads to a reduction of carotenoids and causes the bleaching symptoms (albinism) that are typical of this mode of action (Mitchell et al., 2001). Plants which are susceptible to mesotrione present leaf chlorosis three days after application evolving to widespread necrosis and death of the plant within 2 weeks (Pallet et al., 1998).

\section{Materials and Methods}

Field experiment entitled "Physiological investigations on response of post emergence application of weedicides in maize [Zea mays (L.)]" was conducted at Research Farm AICRP on Forage Crops, Department of Agronomy, Jawaharlal Nehru Krishi Vishwa Vidyalaya, Jabalpur (Madhya Pradesh) during Kharif season of 2018. The experimental field having a gentle slope, proper drainage and uniform clay loam soil was selected. The research experiment was laid out in a randomized block design replicated thrice. The soil of the experimental field was found to be low in organic carbon as well as with medium available nitrogen, medium available phosphorus and medium in available potassium with an average $\mathrm{pH}$ of 7.3 . The total rainfall received during crop season was $1098.7 \mathrm{~mm}$, which was equally distributed in 46 rainy days from June second week to last week of October. Therefore crop did not suffer due to adverse effect of rains on the crop. The maximum and minimum temperature ranged between 37.6 and $17.9^{\circ} \mathrm{C}$. The field was prepared by tilling the land twice with tractor driven cultivator followed by two cross harrowing with disc harrow to obtain a good tilth. A uniform dose of $80 \mathrm{~kg}$ $\mathrm{N}+40 \mathrm{~kg} \mathrm{P}_{2} \mathrm{O}_{5}+20 \mathrm{~kg} \mathrm{~K}_{2} \mathrm{O}$ ha $^{-1}$ was given to all plots then the treatments were laid out on well prepared seed bed as per plan of layout in the experimental field. Growth analytical parameters viz. LAI and LAD among the treatments were recorded. CGR, RGR, NAR, SLA and SLW were analyzed 
during 30-100 days interval. The physiological traits chlorophyll content index was quantified by chlorophyll meter. Observations related to yield was recorded at harvest. Biochemical estimations in seeds viz. Protein content, Fiber content, Total Carbohydrate content, Ash content, Total Fat content was carried out using method suggested by (AOAC, 1965) and (AOAC, 1984).

\section{Results and Discussion}

Total dry matter production and distribution in vegetative organs such as stem, leaf, and sheath ultimately determine maize grain yield (Huang et al., 2007). The dry matter production highly influenced the plant biomass production and grain yield of the crop (Khan et al., 2017). Leaves are the major source of dry matter production through photosynthesis and then accumulated into various plant parts through different physiological processes (Khan et al., 2017). Stem reserves are mobilized during grain filling and the proportion of these reserves in final grain mass depend on cultivar attributes, such as source-sink ratio (Hokmalipour and Darbandi, 2011). Cobs comprised approximately $15 \%$ of the dry matter of corn stover biomass (Shinners and Binversie, 2007). Dry matter production and its partitioning in different plant parts were noted at 30 DAS and at crop maturity. Different treatment had significant effect on dry matter production and maximum accumulation of dry weight at 30 DAS (1.861 gplant $\left.{ }^{-1}\right)$ and at 100 DAS (346.03 gplant $^{-1}$ ) was found in hand weeding. The leaf dry weight increased initially thereafter declined sharply due to translocation of photo assimilates to the developing sink.

The different weed control method had significant effect on growth analytical parameters like LAI, LAD, CGR and RGR.
LAI is a determinant factor in many physiological and agronomic processes, particularly in terms of growth, photosynthesis, transpiration, water and nutrients use and productivity (Gao et al., 2012). Leaf area index (LAI) and leaf area duration (LAD) attained its peak value at 75 DAS thereafter it will decline continuously. Hand weeding (3.25 \& $66219.62 \mathrm{~cm}^{2}$.day) indicated an average highest LAI and LAD. Highest crop growth rate (CGR) was found during flowering stage (45-60 DAS) which was declined at cob development, grain filling and maturity periods (Sorte et al., 2005). Reduction in growth rate with plant age was probably due to cessation of vegetative growth, loss of leaves, and senescence (Tajul et al., 2013). The present study revealed that the hand weeding $\left(0.008879 \mathrm{gcm}^{-2} \mathrm{day}^{-1}\right)$ had the maximum CGR and minimum was found in control $\left(0.006977 \mathrm{gcm}^{-2} \mathrm{day}^{-1}\right)$. Control $\left(0.08446 \mathrm{gg}^{-1} \mathrm{day}^{-1}\right)$ had the maximum relative growth rate (RGR) whereas application of tembotrione 34.4\%SC@ 286mlha ${ }^{-1}$ (0.07493 $\mathrm{gg}^{-1} \mathrm{day}^{-1}$ ) recorded the minimum. Treatments did not exhibit any significant difference among them with respect to NAR, SLA and SLW. Control recorded highest value $\left(0.00410 \mathrm{gcm}^{-2} \mathrm{day}^{-1}\right)$ for Net assimilation rate (NAR) and specific leaf area (SLA) $\left(163.342 \mathrm{~cm}^{2} \mathrm{~g}^{-1}\right)$. On the other end tembotrione $34.3 \%$ SC @ 286 $\mathrm{mlha}^{-1}$ noted maximum value $\left(0.0086 \mathrm{gcm}^{2}\right)$ for specific leaf weight (SLW). SPAD reading values increased quadratically as maize growth and development proceeded from three expanded leaves towards silking (Argenta et al., 2004). Increase in chlorophyll content is considered to be a parameter which corresponds to an increase in photosynthesis, and consequently to an increase in production potential and plant vigour (Bashan et al., 2006). Present investigations revealed that hand weeding exhibited an average maximum CCI (23.52), a peak at 60 DAS followed by a subsequent decline during rest of period (Table 1-3). 
Table.1 Dry matter production, partitioning $\left(\mathrm{g}\right.$ plant ${ }^{-1}$ ) and physiological parameters in maize as influenced by various herbicide treatments

\begin{tabular}{|c|c|c|c|c|c|c|c|c|c|c|c|}
\hline & Treatments & Dry & (g) & lays & & Dry & $\begin{array}{l}\text { ight at } \\
\qquad(\mathrm{g})\end{array}$ & days & & $\begin{array}{c}\text { RGR } \\
\left(\text { g g }^{-1} \text { day }\right)\end{array}$ & $\begin{array}{c}\text { CGR } \\
\left(\mathrm{g} \mathrm{cm}^{-2} \text { day }^{-1}\right)\end{array}$ \\
\hline & Mesotrione 40\% SC @ & Leaf & Stem & TDM & Leaf & Stem & Tassel & Cob & TDM & & \\
\hline$T 1$ & $250 \mathrm{ml} \mathrm{ha} a^{-1}$ & 0.77 & 0.34 & 1.12 & 48.25 & 128.83 & 13.27 & 103.85 & 294.21 & 0.07992 & 0.007700 \\
\hline$T 2$ & $\begin{array}{c}\text { Mesotrione 40\% SC } \\
\text { @ 300ml ha-1 }\end{array}$ & 0.87 & 0.39 & 1.27 & 49.50 & 132.35 & 13.65 & 109.93 & 305.44 & 0.07847 & 0.007933 \\
\hline$T 3$ & $\begin{array}{c}\text { Mesotrione } 40 \% \mathrm{SC} \\
\text { @350ml ha-1 }\end{array}$ & 0.97 & 0.45 & 1.42 & 51.10 & 137.09 & 13.74 & 111.95 & 313.89 & 0.07718 & 0.008063 \\
\hline$T 4$ & $\begin{array}{l}\text { Paraquat dichloride } \\
24 \% S L @ 2000 m l \text { ha-1 }\end{array}$ & 0.69 & 0.30 & 1.00 & 47.68 & 121.62 & 13.28 & 99.45 & 282.03 & 0.08106 & 0.007432 \\
\hline$T 5$ & $\begin{array}{l}\text { Tembotrione } 34.4 \% \\
\text { SC @ 286ml ha }\end{array}$ & 1.15 & 0.58 & 1.76 & 53.34 & 142.88 & 13.93 & 116.75 & 326.90 & 0.07493 & 0.008337 \\
\hline T6 & $\begin{array}{l}\text { Hand weeding } \\
\text { (weed free) }\end{array}$ & 1.24 & 0.61 & 1.86 & 57.34 & 151.11 & 14.40 & 123.17 & 346.03 & 0.07497 & 0.008879 \\
\hline$T 7$ & Control (untreated) & 0.53 & 0.23 & 0.76 & 46.65 & 117.37 & 12.52 & 93.40 & 269.95 & 0.08446 & 0.006977 \\
\hline & S.Em \pm & 0.07 & 0.03 & 0.11 & 1.56 & 1.34 & 0.18 & 3.29 & 3.29 & 0.0013 & 0.0001 \\
\hline & CD (AT $5 \%)$ & 0.23 & 0.11 & 0.35 & 4.81 & 4.13 & 0.56 & 10.13 & 10.14 & 0.0040 & 0.0003 \\
\hline
\end{tabular}


Table.2 Different growth analytical parameters of maize as influenced by various herbicide treatments

\begin{tabular}{|c|c|c|c|c|c|c|c|c|c|c|}
\hline \multirow{2}{*}{\multicolumn{2}{|c|}{ TREATMENTS }} & \multirow{3}{*}{$\begin{array}{c}\text { LAI } \\
3.015\end{array}$} & \multirow{3}{*}{$\begin{array}{c}\begin{array}{c}\text { LAD } \\
\left(\mathbf{c m}^{2} . \text { days }\right)\end{array} \\
62205.67\end{array}$} & \multirow{3}{*}{$\begin{array}{c}\begin{array}{c}\text { NAR } \\
\left(\mathbf{g ~ c m}^{-2} \text { day }^{-1}\right)\end{array} \\
0.00401\end{array}$} & \multirow{3}{*}{$\begin{array}{c}\begin{array}{c}\text { SLA } \\
\left(\mathbf{c m}^{\mathbf{2}} \mathbf{g}^{-1}\right)\end{array} \\
134.89\end{array}$} & \multirow{3}{*}{$\begin{array}{c}\begin{array}{c}\text { SLW } \\
\left(\mathbf{g ~ c m}^{-2}\right)\end{array} \\
0.00841\end{array}$} & \multirow{2}{*}{\multicolumn{4}{|c|}{ CCI }} \\
\hline & & & & & & & & & & \\
\hline T1 & $\begin{array}{c}\text { Mesotrione 40\% SC @ 250ml } \\
\text { ha }^{-1}\end{array}$ & & & & & & $\begin{array}{c}\text { 60 DAS } \\
30.39\end{array}$ & $\begin{array}{c}90 \text { DAS } \\
20.05\end{array}$ & $\begin{array}{c}\text { 110 DAS } \\
11.19\end{array}$ & $\begin{array}{c}\text { Average } \\
21.21\end{array}$ \\
\hline$T 2$ & $\begin{array}{c}\text { Mesotrione 40\% SC @300ml } \\
h a^{-1}\end{array}$ & 3.044 & 63373.03 & 0.00391 & 139.183 & 0.00828 & 30.63 & 22.37 & 11.27 & 21.42 \\
\hline$T 3$ & $\begin{array}{c}\text { Mesotrione 40\%SC @350ml } \\
\text { ha }^{-1}\end{array}$ & 3.145 & 65472.13 & 0.00385 & 139.382 & 0.00833 & 31.72 & 21.41 & 11.73 & 21.62 \\
\hline$T 4$ & $\begin{array}{c}\text { Paraquat dichloride 24\%SL } \\
\text { @2000ml ha }{ }^{-1}\end{array}$ & 2.847 & 60335.02 & 0.00414 & 157.405 & 0.00817 & 29.36 & 21.10 & 10.67 & 20.38 \\
\hline$T 5$ & $\begin{array}{l}\text { Tembotrione 34.4\% SC @ } \\
\text { 286ml ha }\end{array}$ & 3.229 & 66090.06 & 0.00387 & 133.652 & 0.00864 & 32.25 & 22.70 & 11.91 & 22.29 \\
\hline T6 & $\begin{array}{l}\text { Hand weeding } \\
\text { (weed free) }\end{array}$ & 3.251 & 66219.62 & 0.00382 & 142.317 & 0.00848 & 35.73 & 22.72 & 12.10 & 23.52 \\
\hline$T 7$ & Control (untreated) & 2.720 & 55999.11 & 0.00410 & 163.342 & 0.00815 & 29.11 & 14.46 & 10.55 & 18.04 \\
\hline & S.Em \pm & 0.053 & 910.64 & 0.0001 & 14.92 & 0.0008 & 0.606 & 0.720 & 0.757 & 0.94 \\
\hline & CD (AT $5 \%)$ & 0.154 & 2705.66 & 0.0002 & 45.98 & 0.0025 & 1.867 & 2.221 & 2.334 & 2.91 \\
\hline
\end{tabular}

Table.3 Yield and quality traits of maize as influenced by various herbicide treatments

\begin{tabular}{|c|c|c|c|c|c|c|c|c|}
\hline \multicolumn{2}{|r|}{ Treatments } & \multirow{2}{*}{$\begin{array}{c}\text { Grain yield } \\
\text { ( kg ha }^{-1} \text { ) } \\
2223.500\end{array}$} & \multirow{2}{*}{$\begin{array}{c}\text { Biological yield } \\
\left.\text { ( kg ha }^{-\mathbf{1}}\right)\end{array}$} & \multirow{2}{*}{$\begin{array}{c}\text { Protein } \\
(\%) \\
9.40\end{array}$} & \multirow{2}{*}{$\begin{array}{l}\text { Fat } \\
(\%) \\
3.70\end{array}$} & \multirow{2}{*}{$\begin{array}{c}\text { Carbohydrate } \\
(\%)\end{array}$} & \multirow{2}{*}{$\begin{array}{c}\text { Fiber } \\
(\%) \\
2.17\end{array}$} & \multirow{2}{*}{$\begin{array}{c}\text { Ash } \\
(\%) \\
1.83\end{array}$} \\
\hline$T 1$ & Mesotrione 40\% SC @250ml ha ${ }^{-l}$ & & & & & & & \\
\hline T3 & Mesotrione 40\%SC @350ml ha ${ }^{-1}$ & 2432.433 & 24722.22 & 9.63 & 3.80 & 70.46 & 2.73 & 2.170 \\
\hline$T 4$ & $\begin{array}{l}\text { Paraquat dichloride 24\%SL @2000ml } \\
\qquad a^{-1}\end{array}$ & 2014.567 & 19666.67 & 9.13 & 3.68 & 66.92 & 2.13 & 1.83 \\
\hline T5 & Tembotrione 34.4\% SC @ 286ml ha ${ }^{-1}$ & 2623.453 & 25611.11 & 9.70 & 4.00 & 66.29 & 2.50 & 2.33 \\
\hline T6 & $\begin{array}{l}\text { Hand weeding } \\
\text { (weed free) }\end{array}$ & 2812.423 & 26055.56 & 9.87 & 3.84 & 68.22 & 2.40 & 2.67 \\
\hline$T 7$ & Control (untreated)s & 1036.533 & 17222.22 & 9.07 & 3.64 & 65.21 & 2.03 & 1.67 \\
\hline & S.Em \pm & 45.52 & 162.19 & 0.079 & 0.059 & 0.494 & 0.134 & 0.199 \\
\hline & CD (AT $5 \%)$ & 140.28 & 499.78 & 0.244 & 0.184 & 1.524 & 0.414 & 0.613 \\
\hline
\end{tabular}


Maximum SPAD values were observed at 60 DAS which declined progressively reaching the lowest at 110 DAS. Control noted an average lowest value (18.04) for this trait. Finding revealed that treatments had significant effect on yields. Highest values of LAI, LAD and CGR at all crop growth stages are desirable for getting higher seed yield qha $^{-1}$ (Tandale and Ubale, 2007), hand weeding recorded maximum grain yield (2812.42 $\mathrm{kgha}^{-1}$ ) and biological yield $\left(26055.56 \mathrm{kgha}^{-1}\right)$. The highest biological yield in the herbicides treated plots was due to the appropriate increase in plant height and attained huge canopy by timely application of the herbicides, which decreased the weed species occurrence that ultimately produced robust crop plants (Khan et al., 2016).

Seed quality parameters indicated that the maximum seed protein (9.87) and fat content (4.00) was estimated in hand weeding. Protein concentration is more sensitive when plants are stressed at advanced stages of development, such as grain filling (Baroowa and Gogoi, 2015). Protein quality and quantity are increased to some extent in high oil corn due to larger germ (including embryo and scutellum) size (White et al., 2007). Carbohydrate (70.46) and fiber content (2.73) found to be more in plot treated with mesotrione 40\% SC@350 $\mathrm{ml} \mathrm{ha}^{-1}$. Our finding were also related to Shaba et al., (2015) who stated that, controlling maize weeds significantly increased the concentrations of carbohydrate percentage in maize grains in comparison to un-weeded control. Highest ash content $(2.67 \%)$ was noted in hand weeding. Control plot registered lowest value for all the traits related to seed quality. The investigations revealed that the application of the entire post emergence weedicides in maize had significant effect on growth related parameters. Use of mesotrione was found effective as indicated by higher yield possessed by the plots sprayed with the herbicides as compared with control (untreated) plot.

\section{References}

Abendroth, LJ, Elmore RW, Boyer MJ and Marlay SK. 2011. Corn Growth and Development. Iowa State Univ. ExtensionPublication\#PMR1009.https://st ore.extension.iastate.edu/Product/CornGrowth-and-Development.

Anonymous 2016.Ministry of Agriculture, Jeofin research desk.

AOAC 1984. Official method of analysis of the association of official Agriculture Chemist, 14th edition, Washington D.C.

AOAC, 1965. Official method of analysis of the association of official Agriculture Chemist, 10th edition Washington D.C.ISBN: 3-9521414-0-2.

Argenta G, Silva PRF and Sangoi L. 2004. Leaf relative chlorophyll content as an indicator parameter to predict nitrogen fertilization. Ciência Rural, Santa Maria, v.34, n.5, p.1379-1387.

Balyan RS and Bhan VM. 1987. Studies on cultural and chemical weed control in maize. Indian J. Agron., 32(1): 41-43.

Baroowa B and Gogoi N. 2015.Changes in plant water status, biochemical attributes and seed quality of black gram and green gram genotype under drought. International Letters of Natural Sciences Vol. 42 (2015) pp 1-1.

Bashan Y, Bustillos. JJ, Leyva JP and Hernandez Bacilio. 2006. Increase in auxiliary photo protective pigment in wheat seedling induced in Azospirilum brasilense. Biol Fertil Soils 42: 279-285.

Gao M, Van der Heijdena G, Vosb J, Eveleensc B, Marcelis L. 2012. Estimation of leaf area for large scale phenotyping and modeling of rose genotypes. Scient. Hortic. P 138.

Hokmalipour S and Darbandi M. 2011. Investigation of nitrogen fertilizer levels on dry matter remobilization of some varieties of corn (Zea mays L.). World Applied Sci. J. 12: 862-870.

Huang ZX, Wang YJ, Wang KJ, Li DH, Zhao M 
and Liu JG. 2007. Photosynthetic characteristics during grain filling stage of summer maize hybrids with high yield potential of $15000 \mathrm{~kg}$ ha-1. Sci. Agric. Sin. 40, 1898-1906.

Khan IA., Hassan G, Malik N, Khan R, Khan H and Khan SA. 2016. Effect of herbicides on yield and yield components of hybrid maize (Zea mays) Planta Daninha, Viçosa-MG, v. 34, n. 4, p.729-736.

Khan S, Khan A, Jalal F, Khan M and Khan H. 2017. Dry Matter Partitioning and Harvest Index of Maize Crop as Influenced by Integration of Sheep Manure and Urea Fertilizer. Adv Crop Sci Tech 5: 276. doi: 10.4172/2329-8863.1000276.

Kogbe JOS. and Adediran JA. 2003. Influence of nitrogen, phosphorus and potassium application on the yield of maize in the savanna zone of Nigeria African Journal of Biotechnology Vol. 2 (10), pp. 345349.

Mitchell G, Bartlett DW, Fraser TEM, Hawkes TR, Holt DC, Townson JK and Wiehert RA. 2001. Mesotrione: a new selective herbicide for use in maize. Pesr. Manair. Sci. 57: 120- 128.

NielsenRL.2010.KernelDevelopmentStagesinCor nhttps://www.agry.purdue.edu/ext/corn/pu bs/corn-03.htm.

Pallett KE, Little JP, Sheekey M and Veerasekaran P. 1998. The mode of action of isoxaflutole: I Physiological effects, metabolism, and selectivity. Pestic. Biochem. Phvsiol. 62: 113-124.

Pimentel D and Patzek TW. 2005 Ethanol Production Using Corn, Switch grass, and Wood; Biodiesel Production Using Soybean and Sunflower Natural Resources Research Volume 14, Issue 1, pp 65-76.

PPDB (Pesticide Properties Data Base). 2014. The
FOOTPRINT Pesticide Properties Database. University of Hertfordshire, UKhttp://sitem.herts.ac.uk/aeru/footprint/e s /index2.htm (Accessed 21 March 2016).

Rodrigues BN, Almeida FS. 2005. Guia de herbicidas. 5.ed. Londrina: IAPAR.

Shaba A,Z.R. Yehia, SA., Safina and. Abo RG, Hassan El.2015.Effect of some maize herbicides on weeds and yield and residual effect on some following crops (Wheat and Broad Bean) Am-Euras. J. Agric. \& Environ. Sci., 15 (6): 1004-1011.

Shinners KJ and Binversie BN. 2007. Fractional yield and moisture of corn stover biomass produced in the Northern US Corn Belt. Biomass Bioenergy, 31: 576-584.

Sorte N, Phad V, Sripriya Balachandran KM and Anitha C.2005.Evaluation of maize composites on their morpho-physiological performance. Journal of Soils and Crops, 15 (2): 452-456.

Suleiman R, Rosentraterk A, and Bern CJ. 2015. Evaluation of maize weevils Sitophilus zeamais Motschulsky infestation on seven varieties of maize. Journal of Stored Products Research Volume 64, Part A, Pages 97-102.

Tajul MI, Alam MM, Hossain SMM, Naher K, Rafii MY and Latif MA. 2013. Influence of Plant Population and NitrogenFertilizer at Various Levels on Growth and Growth Efficiency of Maize the Scientific World Journal 2013(1):193018.

Tandale, M.D. and Ubale, S.S. (2007). Evaluation of growth parameters (AGR, RGR and NAR) in relation to seed yield of soybean. Internat. J. agric. Sci., 3 (1): 102- 106.

White PJ, Pollak LM, Duvick S. 2007. Improving the fatty acid composition of corn oil by using germplasm introgression. Lipid Techol 19:35-38.

\section{How to cite this article:}

Satyendra Thakur, A. S. Gontia and Rohit Kumar Kumawat. 2020. Physiological Investigations on Response of Post Emergence Application of Weedicides in Maize [Zea mays (L.)]. Int.J.Curr.Microbiol.App.Sci. 9(12): 797-803. doi: https://doi.org/10.20546/ijcmas.2020.912.095 